\title{
IMPACT OF WEFT YARN TYPE AND FABRIC WEFT DENSITY ON BURNING BEHAVIOR, TEARING STRENGTH AND AIR PERMEABILITY FOR DIFFERENT TYPES OF ANTIBACTERIAL DRAPERY FABRICS
}

\author{
Erhan Kenan Çeven', Gizem Karakan Günaydin ${ }^{2 *}$, Nejla Çeven ${ }^{3}$
}

\author{
${ }^{1}$ Bursa Uludağ University, Department of Textile Engineering, Nilüfer, Bursa,Turkey \\ ${ }^{2}$ Pamukkale University, Buldan Vocational School, Fashion \& Design Programme, \\ Buldan Denizli, Turkey \\ ${ }^{3}$ Mega Tekstil San. ve Tic.A.Ş., Nilüfer Bursa, Turkey \\ *e-mail: ggunaydin@pau.edu.tr
}

Scientific paper

UDC: 677-037:684.7:614.8

doi: $10.5937 /$ tekstind2101004K

\begin{abstract}
Drapery fabrics are textile products utilized for home and decorative textiles. Recently there have been new functional requirements for the drapery fabrics such as flame retardancy, antimicrobial efficiency, UV protection, etc. This study has been conducted to investigate the effect of weft yarn type and weft density on drapery fabrics' burning behaviour, tearing strength and air permeability properties. "A special inherently flame-retardant yarn" was used as the warp and weft yarns of the woven drapery fabrics while "a special inherently and antibacterial yarn" was also used as the weft yarn in some of the sample groups. Two main fabric groups each consisting of 12 woven drapery samples with different weft yarns and weft densities were separately evaluated among themselves by using SPSS Statistical software package and bar graphs. Burning behaviours of the samples in terms of damage length and damage width with the ignition source were satisfying both for the drapery samples with the special inherently flame-retardant weft yarn as well as those with the special inherently flame retardant and antibacterial yarn weft yarns. In other words, usage of inherently flame retardant and antibacterial yarn as the weft yarns did not contribute negatively on the flame retardancy of drapery fabrics. The results of two-way ANOVA test indicated that weft yarn type was a significant factor for tearing strength in warp and weft wise while weft density and the interaction of weft yarn type and weft density factors were non-significant factors on tear strength values in warp and weft wises at significance level of 0.05. Additionally, correlation analyses revealed that weft yarn tenacity values were highly correlated with the drapery fabrics' weft tearing strength values. Moreover, weft yarn type, weft density and their interaction were influential factors on air permeability of the drapery fabrics at significance level of 0.05 .
\end{abstract}

Keywords: Drapery fabrics, flame retardancy, tear strength, air permeability, antimicrobial efficiency.

\section{UTICAJ TIPA PREDIVA POTKE I GUSTINE POTKE NA PONAŠANJE PRI SAGOREVANJU, SNAGU CEPANJA I PROPUSNOSTI VAZDUHA ZA RAZLIČITE VRSTE ANTIBAKTERIJSKIH TKANINA ZA DRAPERIJE}

Apstrakt: Draperije su tekstilni proizvodi koji se koriste u kući i kao dekorativni tekstil. Odskora se javio novi funkcionalni zahtev po pitanju materijala za draperije, kao što je usporavanje plamena, antimikrobna efikasnost, UV zaštita i tome slično. Ova studija je sprovedena kako bi se istražio uticaj tipa prediva potke i gustine 
potke na ponašanje tkanine za draperiju pri gorenju, na čvrstoću pri cepanju i na propusnost vazduha. "Posebno predivo koja usporava plamen" korišćeno je kao osnova i potka prediva od pletenih tkanina za draperije, dok se "posebna svojstveno i antibakterijsko predivo" takođe koristilo kao predivo potke u nekim od grupa uzoraka. Dve osnovne grupe tkanina, od kojih se svaka sastojala od 12 uzoraka pletenih draperija sa različitim predivima potke i gustinom potke zasebno su procenjene uz pomoć softverskog paketa SPSS i stubičastih grafikona. Ponašanje uzoraka pri sagorevanju u pogledu dužine i širine oštećenja izvorom paljenja je zadovoljavajuće kako po pitanju uzoraka draperija sa posebnim predivom koje usporava plamen tako i u pogledu one sa posebnim inherentno nesagorivim i antibakterijskim predivima potke. Drugim rečima, upotreba inherentno nesagorivog i antibakteriskog prediva kao prediva potke nije negativno doprinela usporavanju plamena draperije. Rezultati two-way ANOVA testa ukazuju na to da je tip prediva potke značajan faktor za snagu cepanja u osnovama i potkama, dok su gustina potke i interakcija tipa prediva potke i faktori gustine potke neznačajni faktori u pogledu vrednosti snage cepanja u osnovama i potkama, na nivou značajnosti 0.05. Dodatno, korelacionim analizama otkriveno je da su vrednosti čvrstine prediva potke u visokoj korelaciji sa vrednostima snage cepanja tkanine. Štaviše, vrsta prediva potke, gustina potke i njihova interakcija istakli su se kao uticajni faktori na propusnost vazduha tkanina za draperije, pri nivou značajnosti od 0.05 .

Ključne reči: draperije, usporavanje plamena, snaga cepanja, propusnost vazduha, antimikrobna efikasnost.

\section{INTRODUCTION}

Drapery fabrics have always been used as important decorative textile products. Due to its superior features, polyester is the most frequently used raw material for drapery fabrics. Although drapery fabrics are expected to provide a decorative aspect, some additional technical properties such as acoustic features, thermal insulation, protection from the ultraviolet effect (UV) of sun ray, flame retardancy, etc. should also be considered due to the security requirements for the textiles in big social areas such as theatre halls, show centres, concert areas [1,2].

Fire-retardant fabrics are known to be having more resistivity to the fire compared to others. Some special features may be transferred to textile products through the finishing procedures or by utilizing functional yarns in the textile materials. The methods for reducing the flammability of textiles may be explained with 4 ways: Utilizing high performance fibres such as polyether, ether ketone, polyimides, carbon, glass may be a good alternative as the first method. The second one is the modifying the structures of fibres by copolymerization and chemical modification where the flame-retardant monomer is found in chain structures of fibres. It is also possible to incorporate some flame additives during polymer extrusion such as (bisphenol-S-oligomer derivatives from Toyobo, cyclic phosphonates (Antiblaze CU and 1010 from Rhodia or phosphinate salts from Clariant). The other method for flame retardant textiles is surface treatment with fire retardant chemicals. Adding flame retardants during polymer processing is the most popular one for polyester fibres which is very economic and efficient.
The method of modification of polymer is used on the industrial scale for producing a flameproof fibre. The method of incorporation of comonomeric phosphinic acid into polyester polymeric chain is used for an important example of FR Polyester. Flame retardancy of textile materials are influenced by several factors such as raw material, weaving or knitting type, additives in the fibre, yarn constructions, fabric constructions, treatment type, etc. [3-12].

Some studies in the literature are related to imparting the flame retardancy properties to textile materials. Kotresh et al. performed an investigation about the burning behaviour of commercial flame retardant (FR) polyester curtain fabric samples with varying weights in the range of $300-550 \mathrm{~g} / \mathrm{m}^{2}$ by using cone calorimetry. The weight of the fabric per unit area is found to be influencing the peak heat release rate, rate of heat release (RHR), smoke release and other parameters [13]. Carosio et al. applied a novel method to improve flame retardant properties of textile fabric using multi-layered thin films. PET fabrics were coated with silica nanoparticles using layer-by-layer assembly. Five bilayers of positively and negatively charged colloidal silica ( $<10 \mathrm{~nm}$ average thickness) increased time to ignition and decreased heat release rate peak of PET fabric by $45 \%$ and $20 \%$, respectively [14]. Yang et al. conducted a study related to evaluation and analysing of the flame-retardant textiles. Micro-scale combustion calorimetry (MCC) was used for the evaluation of flammability of different textile fabrics made of cotton, rayon, cellulose acetate, silk, nylon, polyester, polypropylene, Nomex and Kevlar [15].

Recently the emergence of pandemics such as COVID-19, 003 SARS-CoV-1 (Severe Acute Respira- 
tory Syndrome Corona Virus 1) epidemic and 2013 Middle East Respiratory Syndrome (MERS) outbreak resulted with some changes in consumers' desires for the final product [16]. The expectations about the decorative textiles have also been focused on their antimicrobial properties beside with their satisfying non-flammability features. Textile products provide appropriate conditions for the microorganisms such as bacteria and fungi. Those microorganisms are observed everywhere in the environment and may proliferate easily when the required conditions such as moisture, nutrients and temperature are provided. Those microorganisms' growth on textile may lead to some undesired effects on the textile consumers such as unpleasant odour, stains, discoloration, decrement of mechanical strength as well as contamination increment. Hence microorganism generation and their growth on textiles should be minimized by the help of antimicrobial agents or by using antimicrobial fibres or yarns [17-20].

A special inherently antibacterial and flame-retardant yarn was used within our study where they were used as the weft yarns of drapery fabrics. A comparative analyse was performed in order to investigate some physical and functional properties of drapery fabrics with inherently flame retardant and antibacterial weft yarn and the antibacterial treated drapery fabrics with conventional inherently flame-retardant weft yarn. The objective of this study is to explore the effect of utilizing a special multi-functional yarn in drapery fabrics as weft yarn and the effect of a applying a further antibacterial finishing process on some fabric properties such as burning behaviour, tearing strength and air permeability at different weft densities. It is aimed to fill the gap in the literature by conducting a comparative study about the investiga- tion of the flame retardancy, mechanical and air permeability features of the fabrics gained with different ways of antibacterial features. The investigation may provide a valuable approach for the multifunctional flame retardant and antibacterial drapery fabrics.

\section{EXPERIMENTAL}

\subsection{Materials and Preparation}

In the study, total of 24 polyester fabrics varying in different yarn count and yarn structure were woven on Dornier Staubli at different weft densities. The weft yarns used for the woven drapery fabrics are staple polyester yarn (Trevira CS), textured polyester yarn (Trevira CS), antibacterial staple polyester yarn (Trevira CS Bioactive), antibacterial textured polyester yarn (Trevira CS Bioactive), respectively. All weft yarns are inherently flame retardant. The flame-retardant property in the yarns is firmly anchored in the fibre in the form of a comonomer - an organophosphorous compound (Figure 1).

The antibacterial feature for the drapery fabrics is provided whether with utilizing inherently flame retardant and antibacterial weft yarns or provided with an additional surface treatment. The $50 \mathrm{dtex} / 40$ fil, 600 tpm (S direction), trilobal bright textured inherently flame-retardant polyester was utilized as the warp yarn for all fabrics. The 8/1 weft satin Z(3) drapery fabrics having the warp density of 80 threads/ $\mathrm{cm}$ were woven on Dornier Staubli Jacquard Machine at different weft densities. Table 1 and Table 2 displays the experimental design of the study where the fabrics with finer weft yarns and the fabrics with coarser weft yarns were evaluated separately within the study. Illustration of the $8 / 1$ weft satin Z(3) drapery fabrics is also indicated in Figure 2.
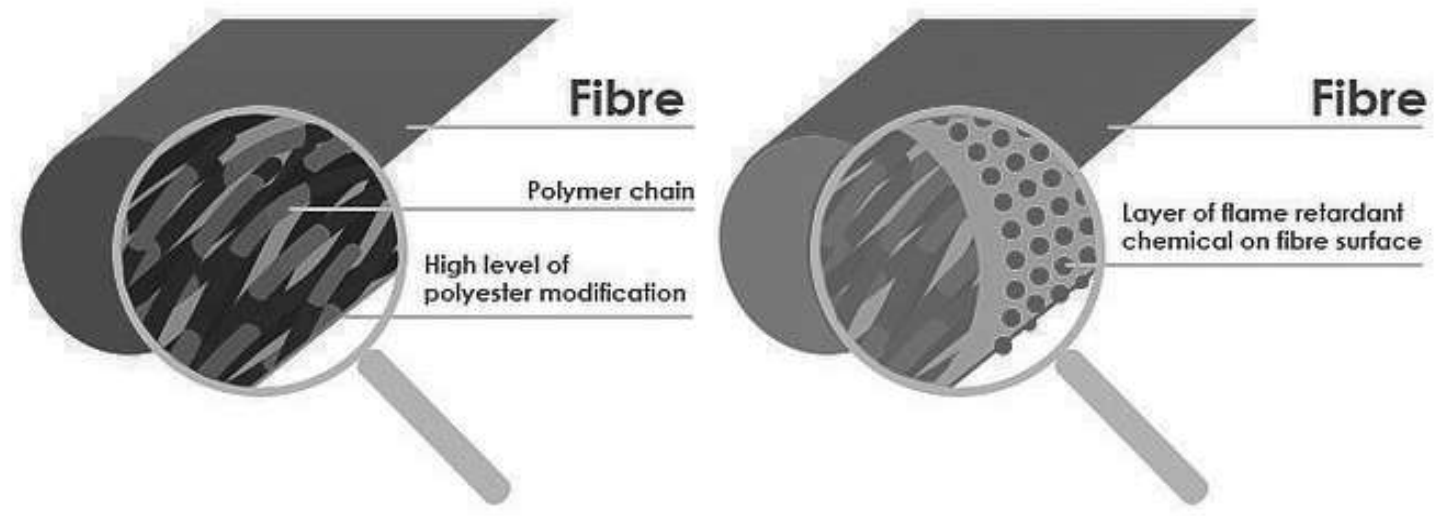

Figure 1: Inherently flame-retardant polymer [21] 
Table 1: Structural properties of $1^{\text {st }}$ group drapery fabrics.

\begin{tabular}{|c|c|c|c|c|c|c|}
\hline $\begin{array}{l}\text { Fabric } \\
\text { code }\end{array}$ & $\begin{array}{l}\text { Weft } \\
\text { yarn } \\
\text { code }\end{array}$ & Weft yarn type & $\begin{array}{l}\text { Weft yarn } \\
\text { count and } \\
\text { yarn twist }\end{array}$ & $\begin{array}{c}\text { Weft yarn } \\
\text { Density } \\
\text { (thread/cm) }\end{array}$ & $\begin{array}{l}\text { Weft yarn } \\
\text { tenacity } \\
\text { (cN/tex) }\end{array}$ & $\begin{array}{l}\text { Way of Gaining } \\
\text { Antibacterial } \\
\text { Feature }\end{array}$ \\
\hline TK138 & TK1 & \multirow{3}{*}{$\begin{array}{l}\text { Staple Polyester yarn } \\
\text { (produced with inherently } \\
\text { flame retardant fibre ) }\end{array}$} & \multirow{3}{*}{$\begin{array}{c}20^{*} 1 \mathrm{Tex} \\
1020 \mathrm{tpm}\end{array}$} & 38 & 523 & \multirow{6}{*}{$\begin{array}{c}\text { Appying } \\
\text { Antibacterial } \\
\text { treatment }\end{array}$} \\
\hline TK144 & TK1 & & & 44 & 523 & \\
\hline TK150 & TK1 & & & 50 & 523 & \\
\hline TT138 & TT1 & \multirow{3}{*}{$\begin{array}{l}\text { Textured Semi dull } \\
\text { Polyester Yarn (produced } \\
\text { with inherently flame } \\
\text { retardant fibre) }\end{array}$} & \multirow{3}{*}{$\begin{array}{l}17 \text { Tex/64 } \\
\text { filament } \\
300 \mathrm{~S}\end{array}$} & 38 & 626 & \\
\hline TT144 & TT1 & & & 44 & 626 & \\
\hline TT150 & TT1 & & & 50 & 626 & \\
\hline AK138 & AK1 & \multirow{3}{*}{$\begin{array}{l}\text { Staple Polyester yarn } \\
\text { (Produced with inherently } \\
\text { flame retardant and } \\
\text { antibacterial fibre) }\end{array}$} & \multirow{3}{*}{$\begin{array}{c}20 * 1 \mathrm{Tex} \\
1020 \mathrm{tpm}\end{array}$} & 38 & 440 & \multirow{6}{*}{$\begin{array}{l}\text { Using inherently } \\
\text { antibacterial } \\
\text { fibre }\end{array}$} \\
\hline AK144 & AK1 & & & 44 & 440 & \\
\hline AK150 & AK1 & & & 50 & 440 & \\
\hline AT138 & AT1 & \multirow{3}{*}{$\begin{array}{l}\text { Textured Semi dull } \\
\text { Polyester Yarn (produced } \\
\text { with inherently flame } \\
\text { retardant and antibacterial } \\
\text { fibre) }\end{array}$} & \multirow{3}{*}{$\begin{array}{l}17 \text { Tex/64 } \\
\text { filament } \\
300 \mathrm{~S}\end{array}$} & 38 & 605 & \\
\hline AT144 & AT1 & & & 44 & 605 & \\
\hline AT150 & AT1 & & & 50 & 605 & \\
\hline
\end{tabular}

Table 2: Structural properties of $2^{\text {nd }}$ group drapery fabrics

\begin{tabular}{|c|c|c|c|c|c|c|}
\hline $\begin{array}{l}\text { Fabric } \\
\text { code }\end{array}$ & $\begin{array}{l}\text { Weft } \\
\text { yarn } \\
\text { code }\end{array}$ & Weft yarn type & $\begin{array}{l}\text { Weft yarn } \\
\text { count and } \\
\text { yarn twist }\end{array}$ & $\begin{array}{c}\text { Weft yarn } \\
\text { Density } \\
\text { (thread/cm) }\end{array}$ & $\begin{array}{l}\text { Weft yarn } \\
\text { tenacity } \\
\text { (cN/tex) }\end{array}$ & Process \\
\hline TK230 & TK2 & \multirow{3}{*}{$\begin{array}{l}\text { Staple polyester yarn } \\
\text { (produced with inherently } \\
\text { flame retardant fibre ) }\end{array}$} & \multirow{3}{*}{$\begin{array}{c}20 * 2 \text { tex } \\
1020 \text { tpm }\end{array}$} & 30 & 1165 & \multirow{6}{*}{$\begin{array}{l}\text { Applying } \\
\text { Antibacterial } \\
\text { treatment }\end{array}$} \\
\hline TK234 & TK2 & & & 34 & 1165 & \\
\hline TK238 & TK2 & & & 38 & 1165 & \\
\hline TT230 & $\mathrm{TT} 2$ & \multirow{3}{*}{$\begin{array}{l}\text { Textured Semi dull } \\
\text { polyester yarn (produced } \\
\text { with inherently flame } \\
\text { retardant fibre) }\end{array}$} & \multirow{3}{*}{$\begin{array}{c}34 \text { Tex/128 } \\
\text { filament } \\
160 \mathrm{~S}\end{array}$} & 30 & 1164 & \\
\hline TT234 & $\mathrm{TT} 2$ & & & 34 & 1164 & \\
\hline TT238 & TT2 & & & 38 & 1164 & \\
\hline AK230 & AK2 & \multirow{3}{*}{$\begin{array}{l}\text { Staple polyester yarn } \\
\text { (produced with inherently } \\
\text { flame retardant and } \\
\text { antibacterial fibre) }\end{array}$} & \multirow{3}{*}{$\begin{array}{c}20 * 2 \text { tex } \\
1020 \text { tpm }\end{array}$} & 30 & 1115 & \multirow{6}{*}{$\begin{array}{l}\text { Using inherently } \\
\text { antibacterial } \\
\text { fibre }\end{array}$} \\
\hline AK234 & AK2 & & & 34 & 1115 & \\
\hline AK238 & AK2 & & & 38 & 1115 & \\
\hline AT230 & AT2 & \multirow{3}{*}{$\begin{array}{l}\text { Textured Semi dull } \\
\text { polyester yarn (produced } \\
\text { with inherently flame } \\
\text { retardant and antibacterial } \\
\text { fibre) }\end{array}$} & \multirow{3}{*}{$\begin{array}{c}34 \text { Tex/128 } \\
\text { filament } \\
160 \mathrm{~S}\end{array}$} & 30 & 1220 & \\
\hline AT234 & AT2 & & & 34 & 1220 & \\
\hline AT238 & AT2 & & & 38 & 1220 & \\
\hline
\end{tabular}



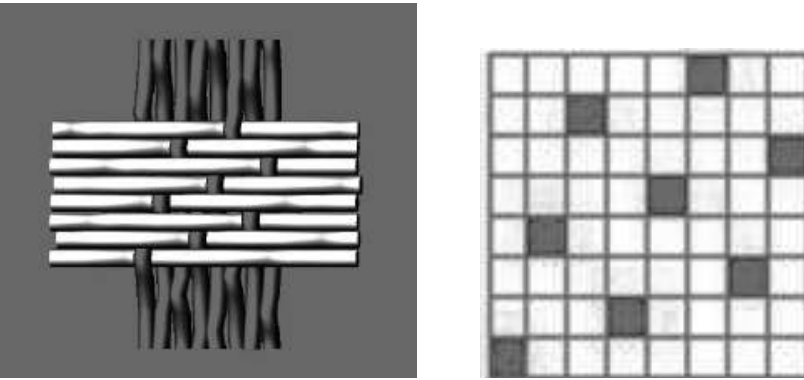

Figure 2: Illustration of satin weave drapery fabrics

For the treated fabric groups, imparting of antibacterial finishing was achieved with the padding system by using antibacterial agent (RucoBac AGP) with the ratio of $4 \mathrm{~g} / \mathrm{l}$ after the fabrics were washed at 70 ${ }^{\circ} \mathrm{C}$. All antibacterial treated or untreated samples were dried and cured in Stenter after wet processes.

\subsection{Method}

Prior to all tests, all fabrics were conditioned for 24 hours in standard atmospheric conditions (at the temperature of $20 \pm 2{ }^{\circ} \mathrm{C}$ and relative humidity of $65 \pm 2 \%$ ). Curtains and drapery fabrics are expected to meet some of the requirements such as flame retardancy, windproof feature as well as satisfying mechanical properties. Hence within our study burning behaviour, tearing strength in warp and weft wise and air permeability properties were evaluated. Each section is discussed with the help of the bar graphs and statistical results, respectively.

\section{Burning Behaviour}

A testing device of NFP 92-503 was used for measuring the damage length and damage width of fabrics in the warp direction for the flammability test. The fabric samples were inclined at $30^{\circ}$ to the horizontal and were subjected to a radiant heat flux for $5 \mathrm{~min}$ utes and flaming ignition source was applied to the heated fabrics. Figure 3 displays the NFP 92-503 Electric Burner Testing device [21]. Damage zone at the length and width in warp and weft wise were recorded in millimetres among the fabrics with the help of the test device (Figure 4).

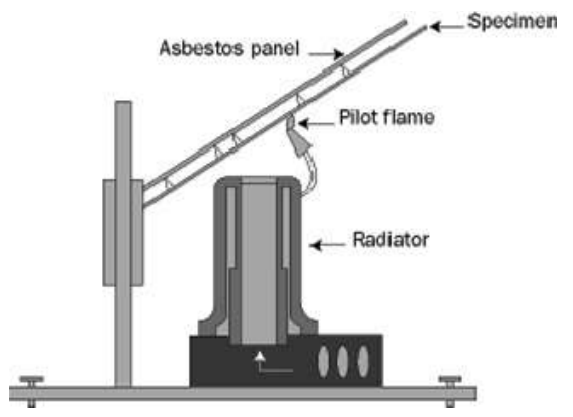

Figure 3: NFP 92-503 Electric Burner Test [22]

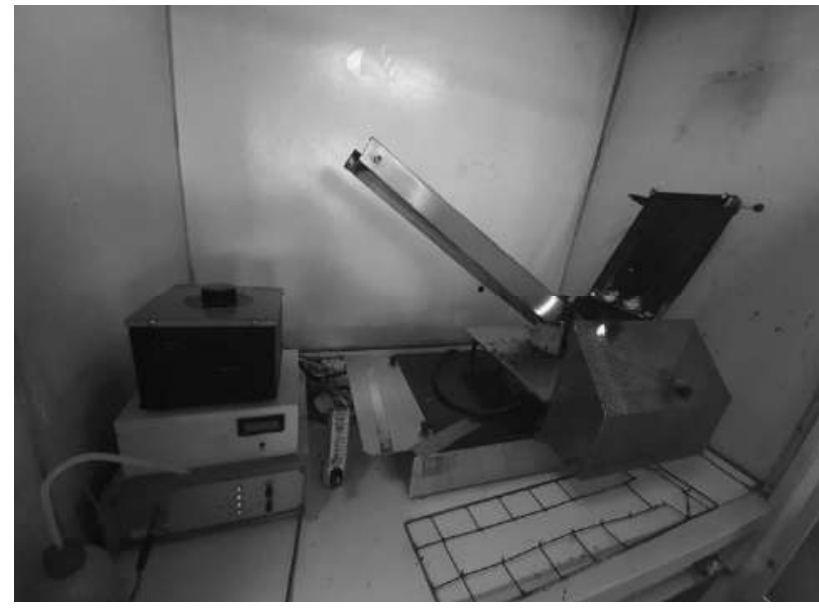

Figure 4: NFP 92-503 Electrical burner test device (Mega Textile Company, Physical Testing and Analysis Laboratory)

\section{Tear Strength}

Tearing may be described as the consecutive breakage of yarn groups along the fabrics. Tear strength may be defined as one of the important mechanical parameters which influences the serviceability of drapery fabrics. This property may be influenced with several factors such as yarn, fabric structure, fabric treatment type, conditions, etc. Single tear method named as 'Determination of tear force of wingshaped test specimens' was utilized for conducting tear strength tests of fabric samples by utilizing Titan - Universal Strength Tester by James H. Heal \& Co. Ltd. test machine (Figure 5). Five samples for weft and five samples for warp tear strength were prepared [23].

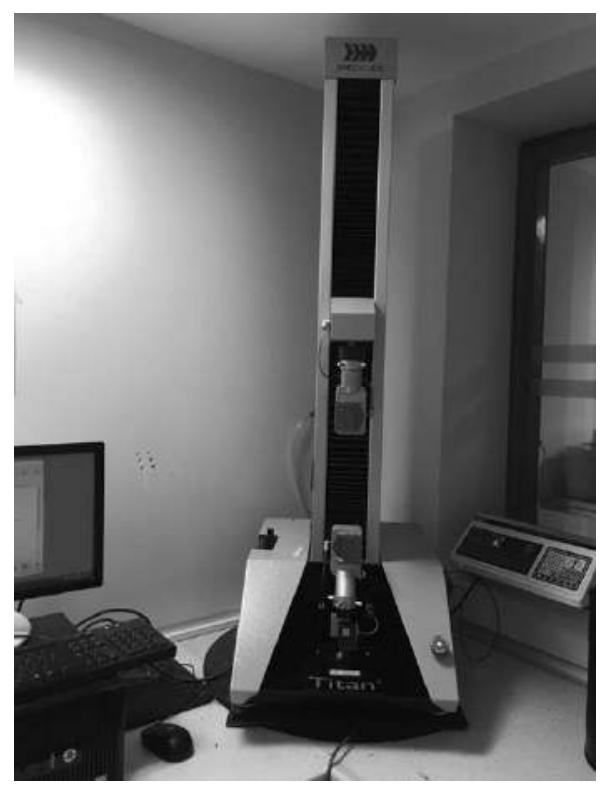

Figure 5: Titan - Universal Strength Tester (Mega Textile Company, Physical Testing and Analysis Laboratory) 


\section{Air Permeability}

Air permeability of drapery fabrics should be considered to guarantee them they are windproof. Air permeability of woven fabrics may be influenced from the yarn type, yarn linear density as well as surface treatment type. Drapery fabrics were subjected to air permeability test with SDL Atlas Digital Air Permeability Tester according to EN ISO 9237 standard [24]. Measurements were performed by application under $100 \mathrm{~Pa}$ air pressure per $20 \mathrm{~cm}^{2}$ fabric surface. Averages of measurements from 10 different areas of fabrics were calculated (Figure 6).

\subsection{Statistical Analyses}

In order to understand the statistical importance of weft yarn type and weft density on tearing strength and air permeability properties of drapery fabrics, two-way ANOVA test was performed. Student-Newman- Keuls (SNK) were also conducted to compare the means of damage width, damage length for tear strength and air permeability of the drapery fabrics. The treatment levels in SNK tests were marked in accordance with the mean values and levels marked by different letter $(a, b, c, d)$ indicating the significant differences. Additionally, Pearson correlation analyses were conducted to obtain the correlation coefficient between yarn tensile properties and fabric tear strength properties. The significance level (a) selected for all statistical tests in the study is 0.05 . All statistical procedures were conducted using the SPSS 23.0 Statistical software package.

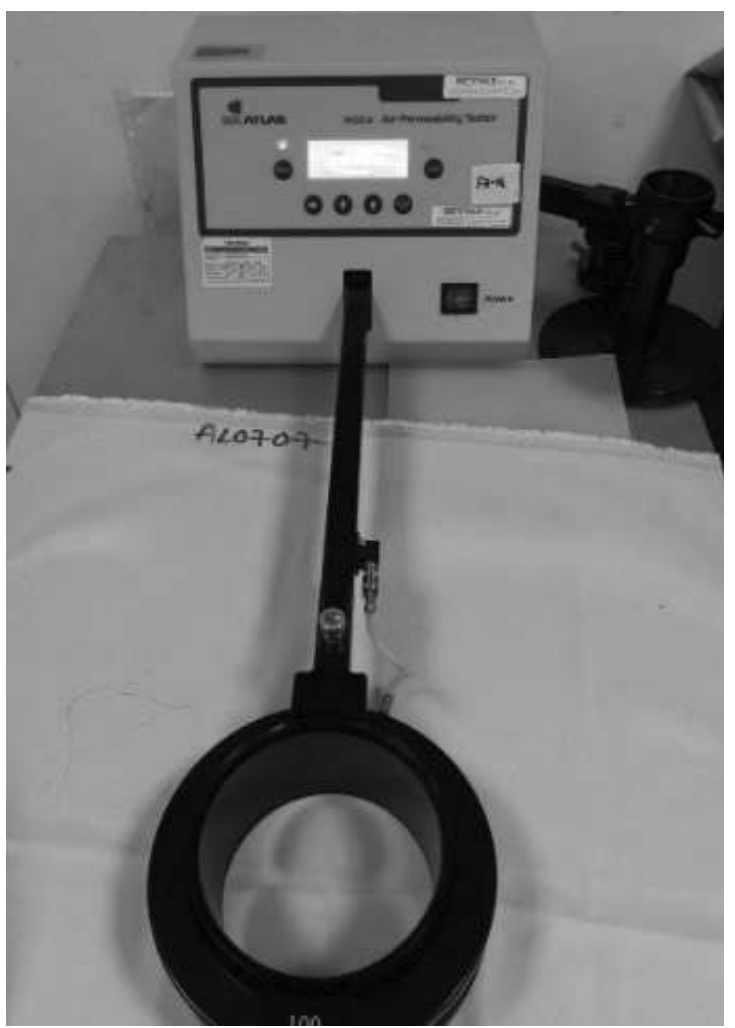

Figure 6: SDL Atlas Digital Air Permeability Tester (Bursa Uludağ University, Textile Engineering Department, Physical Testing and Analysis Laboratory)

\section{RESULTS AND DISCUSSIONS}

\subsection{Analysing of the Burning Behaviour}

Damage zone with the ignition source

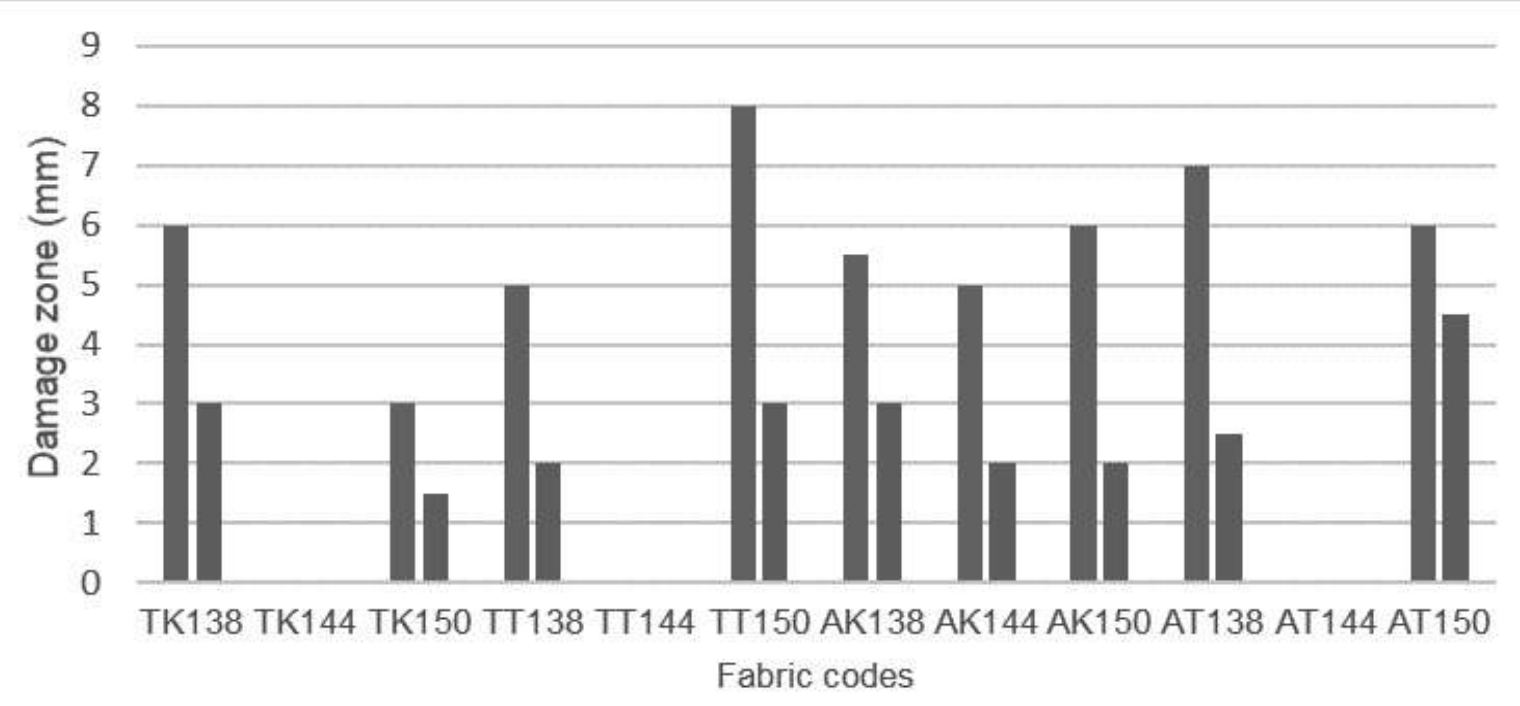

- damage length $\quad$ damage width

Figure 7: Damage zone of the $1^{\text {st }}$ group 


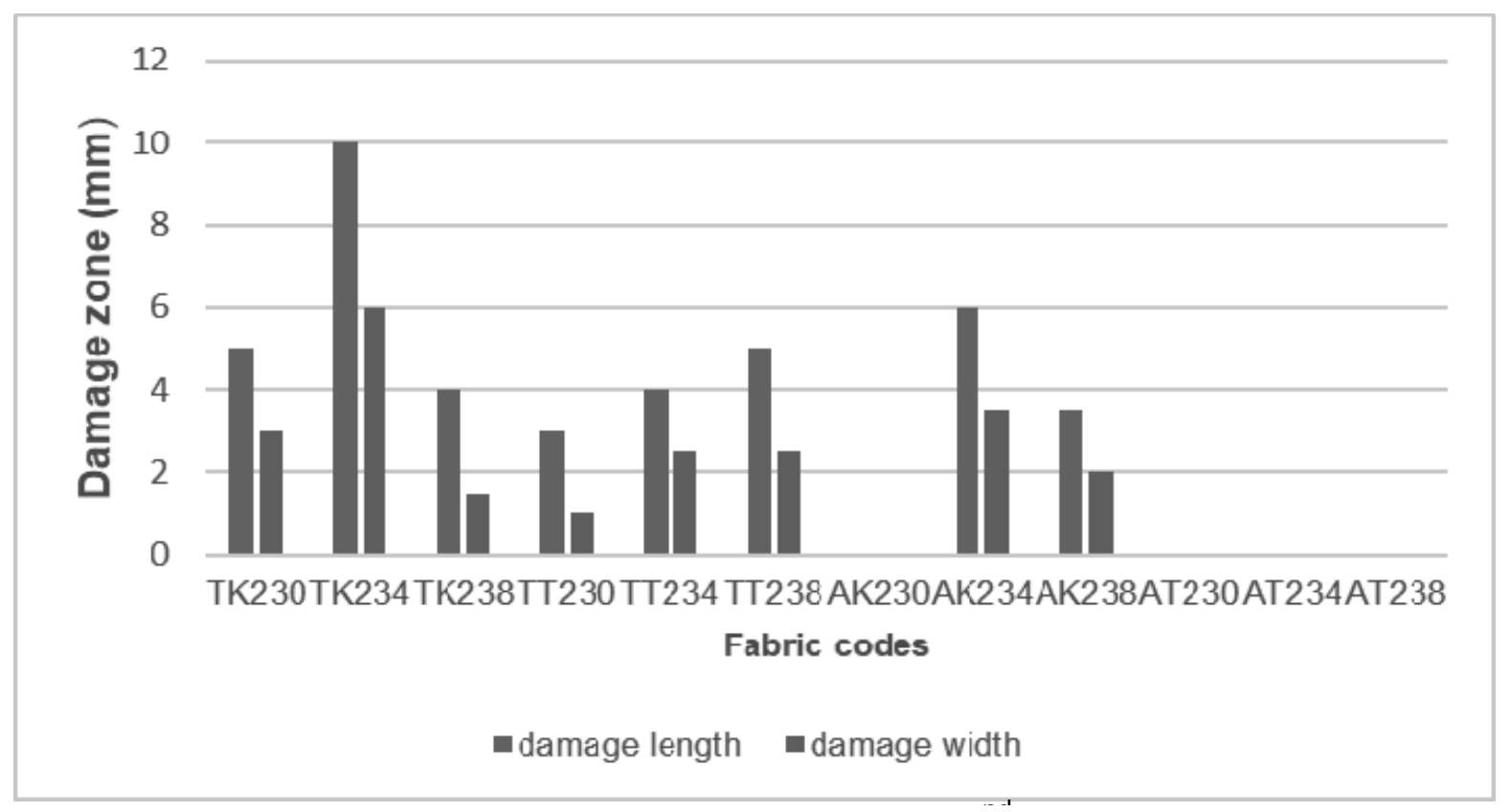

Figure 8: Damage zone of the $2^{\text {nd }}$ group

When the damage zone of the first group fabrics is considered (Figure 7), the highest damage length is obtained from TT150 coded fabrics whereas the highest damage width is obtained from AT150 coded fabrics. There was no damage area observed among the TK144, TT144 and AT144 coded fabrics. It may be generally anticipated that burning behaviours of the drapery fabrics at the weft density of 44 were more satisfying compared to those with the weft density of 38 and 50 threads $/ \mathrm{cm}$. Among the second group of fabrics with coarser weft yarns; the highest damage zone length and damage zone width were obtained from the TK234 coded fabric groups with inherently flame-retardant staple polyester weft yarn produced at 34 threads/cm weft density (Figure 8 ). On the other hand, no longitudinal and transverse damages were observed among the AK230, AT230, AT234, AT238 coded fabrics. Regarding to damaged areas, the samples with inherently flame retardant antibacterial polyester weft yarns were generally more satisfying compared to antibacterial treated samples with inherently flame-retardant polyester weft yarns among the $2^{\text {nd }}$ drapery groups. Another prominent result was the increasing trend of damage zone at the length and width as the weft density increased among the samples with inherently flame-retardant textured polyester weft yarns of 300 denier/128 filament.

As a general evaluation, it can be concluded that ensuring the antibacterial feature of the fabric structure by using inherently antibacterial yarn did not have any negative effect for the performance of fabrics' flame retardancy.

\subsection{Tear Strength}

Figure 9 and Figure 10 indicates the tear strength of $1^{\text {st }}$ and $2^{\text {nd }}$ fabric groups consisting of 12 drapery samples, respectively. According to Figure 9; as the tear strength in warp wise is considered among the $1^{\text {st }}$ group fabrics, it is observed that the tear strength results seem to be decreasing as the weft density increases except for the AT1 coded fabrics. The maximum tear strength in warp wise was obtained from AT150 coded fabrics while the minimum value was obtained from AK150 coded fabrics. When the tear strength in weft wise is considered, the maximum value was observed among AT150 coded fabrics while the minimum value was obtained from TK144 coded fabrics. The decrease of tear strength with the increasing weft density is more prominent in warp wise among the $1^{\text {st }}$ fabric groups. The tearing strength of $2^{\text {nd }}$ drapery fabric groups made of coarser yarns are displayed in Figure 10. it is observed that tearing strength results in warp wise was distinctly lower than tearing strength results in weft wise. The maximum tear strength in warp wise was obtained from AT230 coded fabrics with textured inherently flame retardant and antibacterial weft yarn at 30 threads/cm weft density while the minimum value was obtained from AK238 coded fabrics with staple inherently flame retardant and antibacterial weft yarn at 38 weft density. As the tear strength in weft wise is evaluated, the maximum tear strength in weft wise was obtained from AT230 coded fabrics while minimum value was observed among AK234 coded fabrics. 


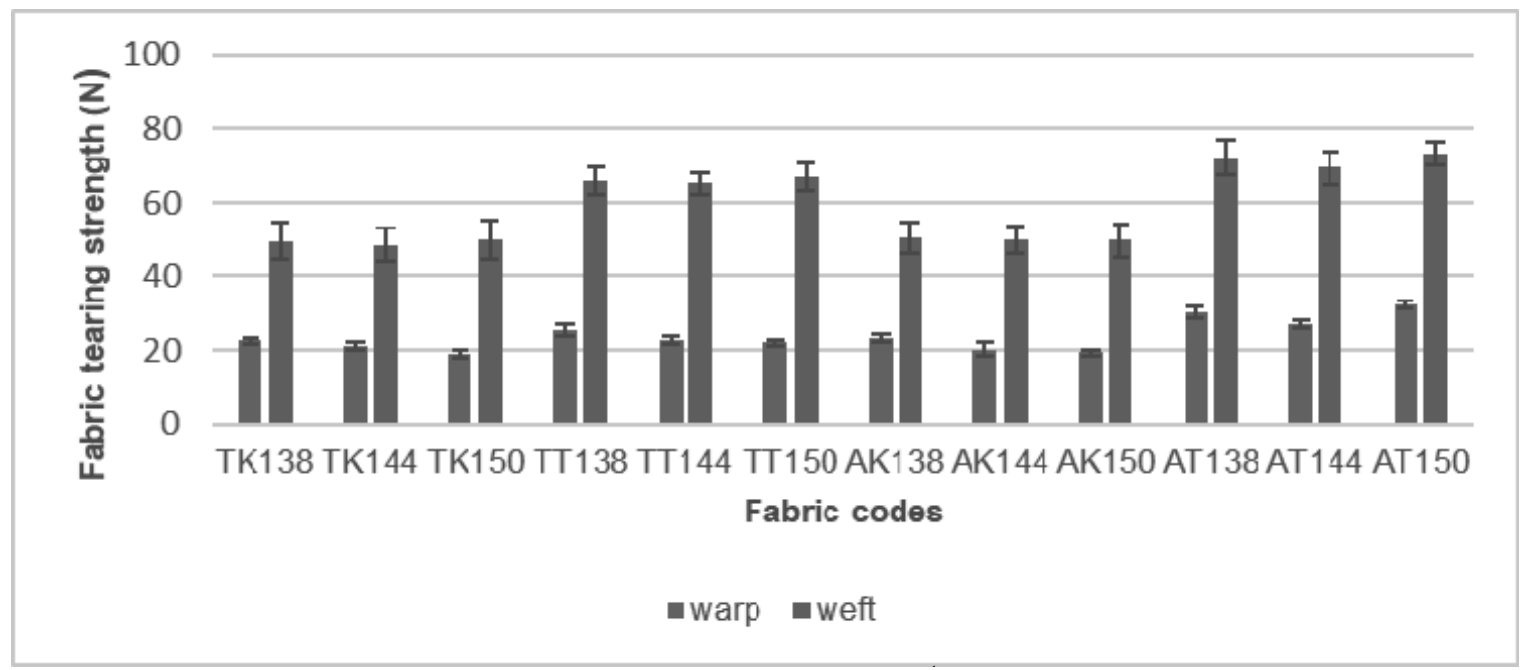

Figure 9: Tear strength $(\mathrm{N})$ of $1^{\text {st }}$ group fabrics

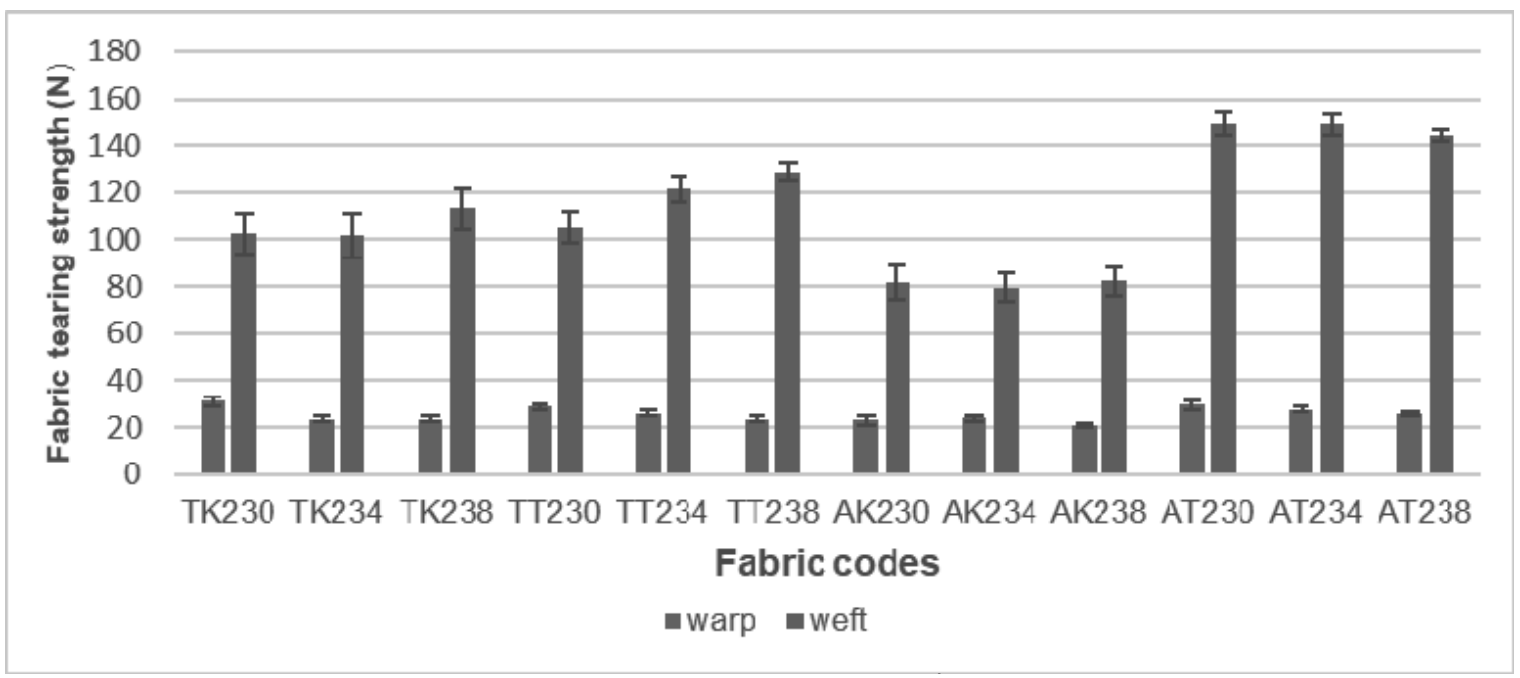

Figure 10: Tear strength $(\mathrm{N})$ of $2^{\text {nd }}$ group fabrics

As the fabric tearing strength values are observed in Figure 9 and Figure 10, it is understood that tearing strength values in weft wise were higher than the tearing strength values in warp wise. This can be attributed to lower fabric density in weft wise compared to warp wise which does not restrict the yarn slippage during tearing process which refers to high tear strength [25]. Considering the both two drapery groups with finer and coarser weft yarns, samples made of textured polyester weft yarns provided more satisfying tearing strength results compared to those made of stapel polyester weft yarns. This result can be seen more clearly especially in the weft direction.

Additionally, in order to observe the significant effect of weft yarn type and weft density on the fabric tear strength in warp and weft wise, two-way ANOVA test was performed. According to ANOVA
Table 3: Univariate two direction ANOVA results for tearing strength

\begin{tabular}{|l|l|c|c|}
\hline \multicolumn{2}{|l|}{$\mathbf{1}^{\text {st }}$ group fabrics } & $\begin{array}{c}\text { Tear } \\
\text { strength in } \\
\text { warp wise }\end{array}$ & $\begin{array}{c}\text { Tear } \\
\text { strength } \\
\text { in weft wise }\end{array}$ \\
\hline Source & Sig.(p) & Sig.(p) \\
\hline $\begin{array}{l}\text { Main } \\
\text { Effect }\end{array}$ & weft yarn type (T) & $0.00^{*}$ & $0.00^{*}$ \\
\cline { 3 - 5 } & Weft density (D) & $0.01^{*}$ & 0.84 \\
\hline Interaction & $T^{*} D$ & 0.05 & 1.0 \\
\hline \multirow{2}{*}{$\mathbf{2}^{\text {nd }}$ group fabrics } & $\begin{array}{c}\text { Tear } \\
\text { strength in } \\
\text { warp wise }\end{array}$ & $\begin{array}{c}\text { Tear } \\
\text { strength in } \\
\text { weft wise }\end{array}$ \\
\hline Source & Sig.(p) & Sig.(p) \\
\hline $\begin{array}{l}\text { Main } \\
\text { Effect }\end{array}$ & weft yarn type (T) & $0.00^{*}$ & $0.00^{*}$ \\
\cline { 3 - 5 } & Weft density (D) & $0.00^{*}$ & 0.23 \\
\hline Interaction & $T^{*} D$ & 0.25 & 0.32 \\
\hline
\end{tabular}

*statistically significant at 0.05 level 
results of $1^{\text {st }}$ group drapery fabrics (Table 3 ), weft yarn type was an influential factor on tearing strength in warp and weft wise at significant level of 0.05 . Weft density was a significant factor on tear strength in warp wise however it was a non-significant factor on tear strength in weft wise. Interaction of weft yarn type and weft density was non-significant on tear strength in warp and weft wise. As ANOVA results of $2^{\text {nd }}$ group drapery fabrics were evaluated (Table 3), the same trend was provided. It is observed that weft yarn type was a significant factor on tear strength in warp and weft wise. On the other hand, weft density was an influential factor only on tear strength in the warp wise while it was non-significant on tear strength in the weft wise at significant level of 0.05 . The interaction of weft yarn type and weft density was non-significant on the tear strength of fabrics in warp and weft wise.

According to SNK results of the $1^{\text {st }}$ group of fabrics (table 4),fabrics made of different weft yarn type and the fabrics woven at different weft densities possessed different tear strength values in warp wise at significance level of 0.05 (Table 4). Additionally, fabrics produced at different weft density possessed different tear strength in warp wise. According to table 4, lowest tear strength in warp direction was observed among the fabrics made of TK1 and AK1 weft yarn type which were observed under the same subset at significance level of 0.05 . The highest tear strength in warp direction was obtained from fabrics with AT1 coded weft yarn type. Positive influence of weft yarn type on tear strength was more apparent among the results in weft direction when compared with the warp direction. Highest tear strength value in weft wise was obtained from drapery fabrics with AT1 coded inherently flame retardant and antibacterial texture polyester weft yarn while lowest tear strength was obtained from samples with TK1 and AK1 coded staple inherently flame retardant and inherently flame retardant-antibacterial staple polyester weft yarns. Considering the weft density; drapery fabrics woven at 38 threads/ $\mathrm{cm}$ weft density revealed the highest tear strength in warp direction whereas the fabrics produced at 44 and 50 threads/cm weft density were observed under the same subset at significance level of 0.05 .

According to SNK results of the second drapery group, Fabrics made of different weft yarn types revealed different tear strength in warp direction at significance level of 0.05 . The samples produced with different weft yarn densities revealed different tearing strength in warp wise. The highest tear strength in warp wise were obtained from the fabrics made of TK2, TT2, AT2 coded weft yarns which were observed under the same subset. Fabric sample with AK2 cod- ed inherently flame retardant and antibacterial staple weft yarn indicated the lowest tear strength in warp wise. When tear strength in weft direction is evaluated, it is observed that minimum value was obtained from fabrics made of AK2 coded staple inherently flame retardant and antibacterial staple weft yarn type while maximum value was obtained from fabrics made of AT2 coded inherently flame retardant and antibacterial textured polyester weft yarn type.

Drapery fabrics produced at different threads/ $\mathrm{cm}$ weft densities possessed different warp tearing strength. Highest value was obtained from the fabrics produced at 30 threads/cm weft density while the drapery fabrics produced at 34 and 38 threads/ $\mathrm{cm}$ weft densities indicated lower value which were observed under the same subset.

Table 4: SNK tests for tear strength of $1^{\text {st }}$ group fabrics

\begin{tabular}{|c|c|c|c|c|}
\hline \multicolumn{5}{|c|}{$\begin{array}{l}\text { Effect of weft yarn type and weft density on tear } \\
\text { strength Student-Newman-Keuls (SNK) }\end{array}$} \\
\hline Parameter & $\begin{array}{l}\text { Tea } \\
\text { in } u \\
\text { dire }\end{array}$ & $\begin{array}{l}\text { trength } \\
\text { rp } \\
\text { tion }\end{array}$ & & $\begin{array}{l}\text { ength } \\
\text { direction }\end{array}$ \\
\hline \multirow{4}{*}{ Weft yarn type } & TK1 & $20.81 \mathrm{a}$ & TK1 & $49.22 \mathrm{a}$ \\
\hline & AK1 & $20.87 a$ & AK1 & $49.92 \mathrm{a}$ \\
\hline & TT1 & $23.32 \mathrm{~b}$ & TT1 & $66.00 \mathrm{~b}$ \\
\hline & AT1 & $29.71 \mathrm{c}$ & AT1 & $71.58 \mathrm{~b}$ \\
\hline \multirow{3}{*}{ Weft Density (D) } & 44 & $22.75 \mathrm{a}$ & 44 & $58.18 \mathrm{a}$ \\
\hline & 50 & $23.07 \mathrm{a}$ & 38 & $59.44 \mathrm{a}$ \\
\hline & 38 & & 50 & 59.92 \\
\hline
\end{tabular}

NOTE: The different letters next to the counts indicate that they are significantly different from each other at a significance level of $5 \%$

Table 5: SNK tests for tear strength of $2^{\text {nd }}$ group fabrics

Effect of weft yarn type and weft density on tear strength Student-Newman-Keuls (SNK)

\begin{tabular}{|l|l|l|l|l|}
\hline \multirow{2}{*}{ Parameter } & \multicolumn{2}{|l|}{$\begin{array}{l}\text { Tear strength } \\
\text { in warp } \\
\text { direction }\end{array}$} & \multicolumn{2}{l}{$\begin{array}{l}\text { Tear strength } \\
\text { in weft } \\
\text { direction }\end{array}$} \\
\hline \multirow{4}{*}{ Weft yarn type } & AK2 & $22.48 \mathrm{a}$ & AK2 & $81.17 \mathrm{a}$ \\
\cline { 2 - 5 } & TK2 & $25.97 \mathrm{~b}$ & TK2 & $106.24 \mathrm{~b}$ \\
\cline { 2 - 5 } & TT2 & $26.07 \mathrm{~b}$ & TT2 & $118.51 \mathrm{c}$ \\
\cline { 2 - 5 } & AT2 & $27.49 \mathrm{~b}$ & AT2 & $147.72 \mathrm{~d}$ \\
\hline \multirow{4}{*}{ Weft Density (D) } & 38 & $23.40 \mathrm{a}$ & 30 & $109.66 \mathrm{a}$ \\
\cline { 2 - 5 } & 34 & $25.13 \mathrm{a}$ & 34 & $112.99 \mathrm{a}$ \\
\cline { 2 - 5 } & 30 & $27.98 \mathrm{~b}$ & 38 & $117.59 \mathrm{a}$ \\
\hline
\end{tabular}

NOTE: The different letters next to the counts indicate that they are significantly different from each other at a significance level of $5 \%$ 
As a general assessment, tear strength results of the drapery fabrics were consisted with their constituent weft yarns. In order to observe the relation between weft yarn tenacity and drapery samples' tear strength; the correlation analyses between the weft yarn tenacity (provided from Table 1) and the weft tear strength values for the $1^{\text {st }}$ group drapery fabrics also the correlation analyses between the weft yarn tenacity (provided from Table 2) and warp tear strength for the $2^{\text {nd }}$ group drapery fabrics were conducted. Table 6 and Table 7 indicates the correlation analyses performed for the $1^{\text {st }}$ group drapery fabrics and the correlation analyses performed for the $2^{\text {nd }}$ group drapery fabrics, respectively.

According the correlation analyse results for the $1^{\text {st }}$ group drapery fabrics indicated in Table 6; weft yarn tenacity was positively correlated with warp tear strength with correlation coefficient of 0.58 , and weft yarn tenacity was also positively correlated with weft tear strength with the correlation coefficient of 0.85 . When it comes to $2^{\text {nd }}$ group, a similar trend was observed for the coefficient results where the weft yarn tenacity was positively correlated with warp tear strength with correlation coefficient of 0.60 and was positively correlated with weft tear strength with the correlation coefficient of 0.95 . Our result was also supported with Can and Kirtay's study where a strong correlation was reported between yarn tensile results and fabric tear strength properties of cotton plain fabrics [26].
Table 6: Correlation between yarn tenacity and fabric tear strength for the $1^{\text {st }}$ group drapery fabrics

\begin{tabular}{|l|l|l|}
\hline Correlations & Plain \\
\hline \multirow{2}{*}{$\begin{array}{l}\text { Weft yarn tenacity } \\
\text { and fabric warp } \\
\text { tear strength }\end{array}$} & $\begin{array}{l}\text { Pearson } \\
\text { Correlation }\end{array}$ & $0.58^{*}$ \\
\cline { 2 - 3 } & Sig. (2-tailed) & 0.01 \\
\cline { 2 - 3 } & $\mathrm{N}$ & 12 \\
\hline \multirow{2}{*}{$\begin{array}{l}\text { Weft yarn tenacity } \\
\text { and fabric weft tear } \\
\text { strength }\end{array}$} & $\begin{array}{l}\text { Pearson } \\
\text { Correlation }\end{array}$ & $\mathbf{0 . 8 5 *}$ \\
\cline { 2 - 3 } & Sig. (2-tailed) & 0.00 \\
\cline { 2 - 3 } & $\mathrm{N}$ & 12 \\
\hline
\end{tabular}

* Correlation is significant at the 0.01 level (2-tailed)

Table 7: Correlation between yarn tenacity and the fabric tear strength for the $2^{\text {nd }}$ group drapery fabrics

\begin{tabular}{|l|l|l|}
\hline \multicolumn{2}{|l|}{ Correlations } & Plain \\
\hline \multirow{2}{*}{$\begin{array}{l}\text { Weft yarn tenacity } \\
\text { and fabric warp tear } \\
\text { strength }\end{array}$} & $\begin{array}{l}\text { Pearson } \\
\text { Correlation }\end{array}$ & $0.60^{*}$ \\
\cline { 2 - 3 } & Sig. (2-tailed) & 0.03 \\
\cline { 2 - 3 } & $\mathrm{N}$ & 12 \\
\hline $\begin{array}{l}\text { Weft yarn tenacity } \\
\text { and fabric weft tear } \\
\text { strength }\end{array}$ & $\begin{array}{l}\text { Pearson } \\
\text { Correlation }\end{array}$ & $0.95^{*}$ \\
\cline { 2 - 3 } & Sig. (2-tailed) & 0.00 \\
\cline { 2 - 3 } & $\mathrm{N}$ & 12 \\
\hline
\end{tabular}

* Correlation is significant at the 0.01 level (2-tailed)

\subsection{Air Permeability}

Figure 11 indicates the air permeability of the $1^{\text {st }}$ group of drapery fabrics produced from different weft yarns at different weft densities. According to figure 11 which reveals the $1^{\text {st }}$ group drapery fabrics; Maximum

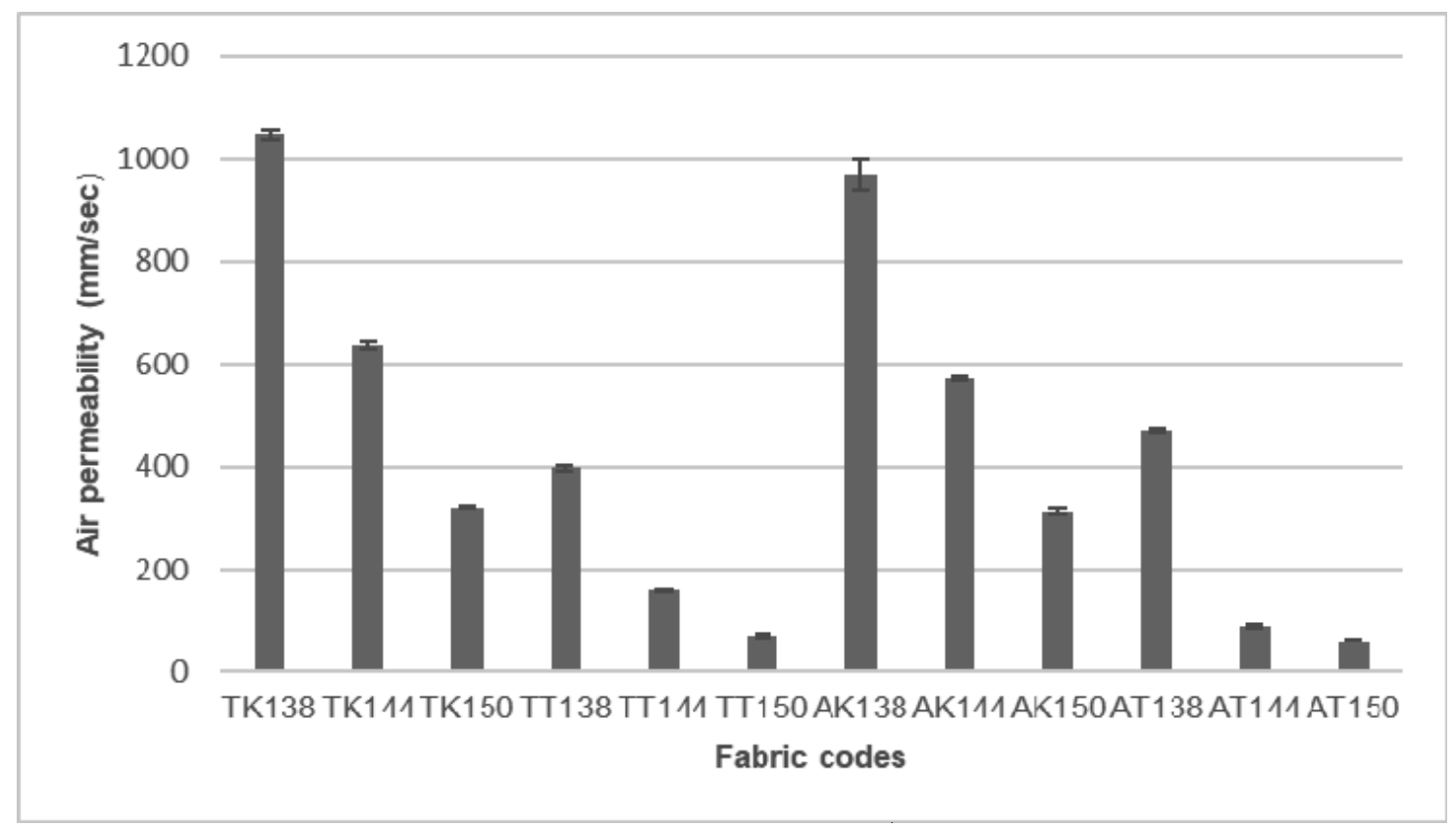

Figure 11: Air permeability of $1^{\text {st }}$ group fabrics 


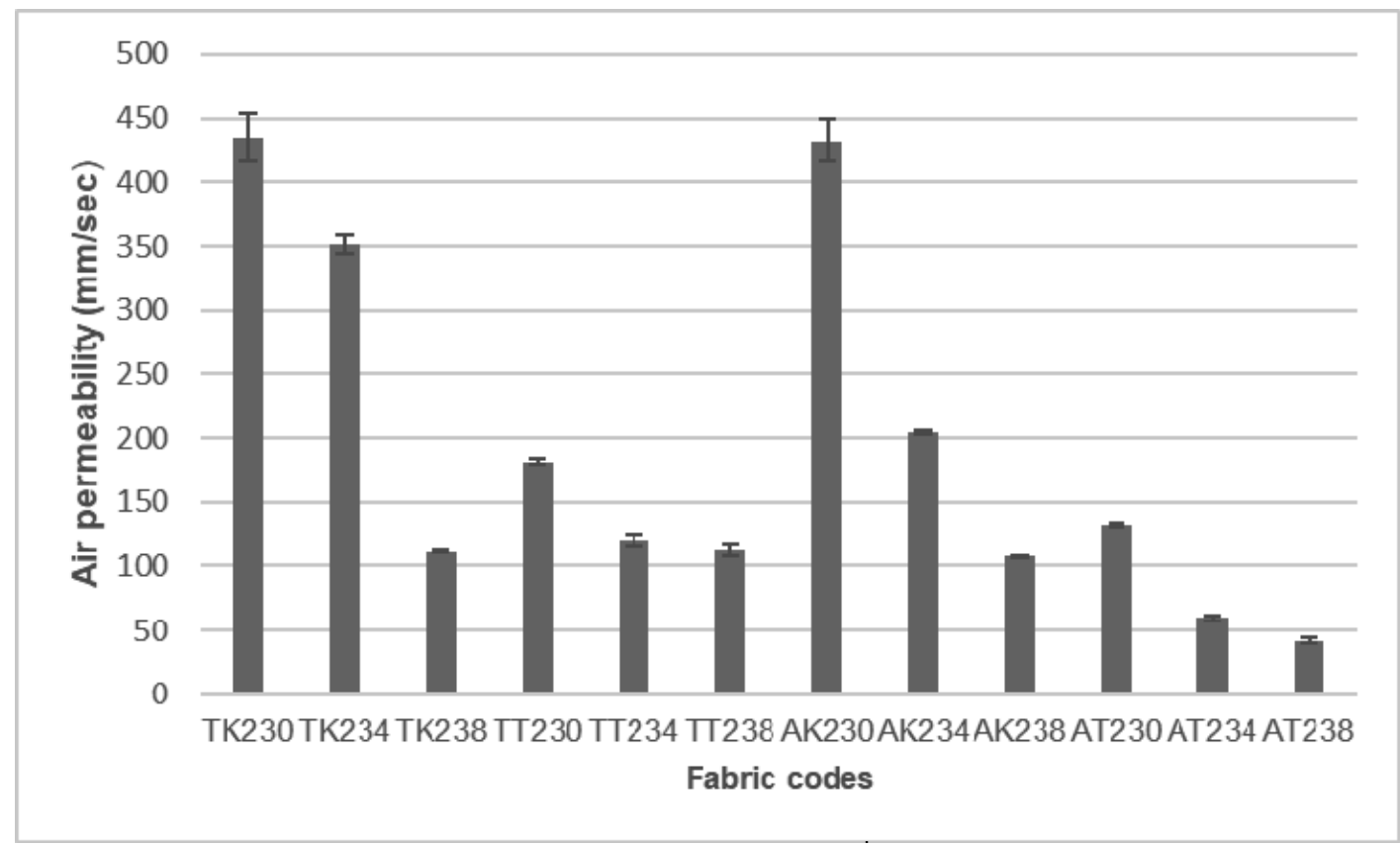

Figure 12: Air permeability of $2^{\text {nd }}$ group fabrics

air permeability was obtained from fabrics made of TK138 coded weft yarn while minimum air permeability was found among fabrics made of TT150 coded weft yarn. There is a prominent decrement for the air permeability of samples made of inherently flame retardant and inherently flame retardant-antibacterial polyester weft yarns as the weft density increases. Additionally, as an expected result; the fabrics with staple weft yarns indicated higher air permeability compared to their counterparts with textured filament weft yarns which may be attributed to high porosity of the fabrics when staple form is used.

Figure 12 reveals the air permeability results of $2^{\text {nd }}$ group of drapery fabrics with coarser weft yarns. According to figure 12; highest air permeability was obtained from TK230 coded fabrics while minimum value was found among the AT238 coded fabrics woven at 38 threads $/ \mathrm{cm}$ weft density. It is prominently observed that air permeability values decreased as the weft density of the fabrics increased. It may be also anticipated that the antibacterial finished fabrics indicated higher air permeability values compared to their untreated counterparts produced from inherently flame retardant and antibacterial yarns.

Additionally, in order to observe the effect of weft yarn type and weft density on the air permeability of drapery fabrics, completely randomized two-way ANOVA was performed among the $1^{\text {st }}$ and $2^{\text {nd }}$ fabric groups (Table 8). Weft yarn type, weft density and the interaction of weft density and weft yarn type were influential factors on the air permeability of $1^{\text {st }}$ group drapery as well as on the air permeability of $2^{\text {nd }}$ group of drapery fabrics at significance level of 0.05 .
Table 8: Univariate two direction ANOVA results for air permeability

\begin{tabular}{|l|l|l|}
\hline \multicolumn{2}{|l|}{$\mathbf{1}^{\text {st }}$ group fabrics } \\
\hline Source & Sig.(p) \\
\hline \multirow{2}{*}{ Main Effect } & weft yarn type (T) & $0.00^{*}$ \\
\cline { 2 - 3 } & weft density (D) & $0.00^{*}$ \\
\hline Interaction & $T^{*} D$ & $0.00^{*}$ \\
\hline $2^{\text {nd }}$ group fabrics \\
\hline Source & Sig.(p) \\
\hline \multirow{2}{*}{ Main Effect } & weft yarn type (T) & $0.00^{*}$ \\
\cline { 2 - 3 } & Weft density (D) & $0.00^{*}$ \\
\hline Interaction & $T^{*} D$ & $0.00^{*}$ \\
\hline
\end{tabular}

*statistically significant at 0.05 level

Table 9: SNK results for air permeability

Effect of weft yarn type and weft density on air permeability Student-Newman-Keuls (SNK)

\begin{tabular}{|l|l|l|l|l|}
\hline Parameter & \multicolumn{3}{|l|}{$1^{\text {st }}$ group } & \multicolumn{2}{l|}{$2^{\text {nd }}$ group } \\
\hline \multirow{4}{*}{$\begin{array}{l}\text { Weft yarn } \\
\text { type }\end{array}$} & AT1 & $96.44 \mathrm{a}$ & AT2 & $78.11 \mathrm{a}$ \\
\cline { 2 - 5 } & TT1 & $209.22 \mathrm{~b}$ & TT2 & $138.66 \mathrm{~b}$ \\
\cline { 2 - 5 } & AK1 & $616.88 \mathrm{c}$ & AK2 & $248.00 \mathrm{c}$ \\
\cline { 2 - 5 } & TK1 & $667.55 \mathrm{~d}$ & TK2 & $299.55 \mathrm{c}$ \\
\hline \multirow{4}{*}{$\begin{array}{l}\text { Weft Density } \\
\text { (D) }\end{array}$} & 50 & $190.66 \mathrm{a}$ & 38 & $93.91 \mathrm{a}$ \\
\cline { 2 - 5 } & 44 & $364.00 \mathrm{~b}$ & 34 & $183.91 \mathrm{~b}$ \\
\cline { 2 - 5 } & 38 & $637.91 \mathrm{c}$ & 30 & $295.41 \mathrm{c}$ \\
\hline
\end{tabular}

NOTE: The different letters next to the counts indicate that they are significantly different from each other at a significance level of $5 \%$ 
SNK results also revealed that fabrics produced with different weft yarn type and the fabrics produced at different weft densities possessed different air permeability values (Table 9). Considering the $1^{\text {st }}$ group of drapery fabrics; minimum air permeability was obtained from the fabrics produced with AT1 coded inherently flame retardant and antibacterial polyester weft yarn as $96.44 \mathrm{~mm} / \mathrm{sec}$ while maximum value was obtained from fabrics with TK1 coded inherently flame retardant staple weft yarn as $667.55 \mathrm{~mm} / \mathrm{sec}$. Considering the weft density the maximum air permeability was observed among the fabrics produced at 38 threads/cm weft density while the minimum air permeability was found among the fabrics produced at 50 threads/cm weft density. When the $2^{\text {nd }}$ group of drapery fabrics are considered, it is observed that minimum air permeability was found among fabrics woven with AT2 coded inherently flame retardant and antibacterial textured weft yarns while maximum air permeability was found among the fabrics with TK2 coded inherently flame-retardant staple polyester weft yarns.

Considering the weft density, the maximum air permeability was observed among the fabrics produced at 30 threads/cm weft density while the minimum air permeability was found among the fabrics produced at 38 threads/cm weft density.

\section{CONCLUSIONS}

This study aims to evaluate the effect of polyester weft yarn type and weft density on burning behaviour, tearing strength and air permeability properties of antibacterial drapery fabrics. Following conclusion can be summarized from the conducted study:

1. Regarding to burning behaviour of the samples, accompanying of antibacterial feature with flame retardancy in the yarn did not contribute negatively for the damage zone $(\mathrm{mm})$ results. There was not a clear trend for the effect of weft density on flame retardancy of the drapery fabrics made of inherently flame-retardant warp and weft yarns.

2. Considering the tear strength; weft yarn type was an influential factor on tearing strength in warp and weft wise at significant factor of 0.05 among the $1^{\text {st }}$ group drapery fabrics also among the $2^{\text {nd }}$ group drapery fabrics. However, weft density was an influential factor only on tear strength in warp wise. There is not a prominent difference for the tear strength of samples with inherently antibacterial weft yarn and the tear strength of the antibacterial treated samples among the $1^{\text {st }}$ group drapery fabrics with finer weft yarn counts at weft densities of $38,44,50$ threads $/ \mathrm{cm}$. However, the difference is much clearer among the $2^{\text {nd }}$ group drapery fabrics with coarser yarn counts at weft densities of 30, 34 and 38 threads/ $\mathrm{cm}$.

3. It can be anticipated that using textured polyester yarns instead of staple revealed more satisfying tear strength results among both groups. Additionally, Pearson correlation analyses also revealed that there was a strong correlation between the weft yarn tenacity values and the fabric tear strength in weft wise.

4. According to statistical results of air permeability, weft yarn type and weft density and the interaction of these two factors were influential on the air permeability property at significance level of 0.05 . It may be also observed that drapery fabrics with staple polyester weft yarn indicated higher air permeability values compared to those with textured polyester weft yarn. Hence it may be anticipated that samples with textured polyester yarns seemed to be revealing better windproof property with lower air permeability values. The increment of weft density resulted with lower air permeability values in both $1^{\text {st }}$ and $2^{\text {nd }}$ fabric groups.

\section{ACKNOWLEDGEMENT}

We wish to express our special thanks to Mega Tekstil San. ve Tic.A.Ş.company for their cooperation during the study.

\section{REFERENCES}

[1] Nassif, G. A. A. (2012). Effect of weave structure and weft density on the physical and mechanical properties of micro polyester woven fabrics, Life Science Journal, 9(3), 1326-1331.

doi: https://doi.org/10.7537/marslsj090312.191

[2] Çeven, E. K., Gürarda, A. (2017). An investigation of performance properties of curtain fabrics produced with different types of polyester yarns, Journal of Textile \& Apparel/Tekstil Ve Konfeksiyon, 27(2), 131-138. 
[3] Dutikova, O. S., Zubkova, N. S., Butylkina, N. G., Konstantinova, N. I., Naganovskii, Y. K. (2005). Flameproofing properties of phosphorus-containing polyester materials, Fibre Chemistry, 37(3), 192-195.

[4] Alongi, J., Carosio, F., Malucelli, G. (2014). Current emerging techniques to impart flame retardancy to fabrics: An overview. Polymer Degradation and Stability, 106, 138-149.

doi: https://doi.org/10.1016/j.polymdegradstab. 2013.07.012.

[5] Chen, L., Wang, Y. (2009). A review on flame retardant technology in China. Part I: development of flame retardants, Polymer Advanced Technologies, 21 (1), 1-26. 10.1002/pat.1550.

[6] Horrocks, A. R. (2019). Smart flame retardant textile coatings and laminates. In Smart Textile Coatings and Laminates, (205-236), Woodhead Publishing.

[7] Horrocks, R., Anand, S.C. (2016). Handbook of technical textiles: Technical fibers for heat and flame protection, Vol 2 (Technical Textile Applications), Woodhead publishing Series in textiles in association with The Textile Institute, Cambridge England.

[8] Horrocks, A.R. (2011). Flame retardant challenges for textiles and fibres: new chemistry versus innovatory solutions, Polymer Degradation and Stability, 96(3), 377-392.

[9] Horrocks, A. R. (2008). Flame retardant/resistant textile coatings and laminates. In Advances in fire retardant materials, 159-187. Woodhead Publishing.

[10] Lawson, D. F. (1986). Recent developments in the flammability of elastomeric materials, Rubber chemistry and technology, 59(3), 455-481.

doi: https://doi.org/10.5254/1.3538210.

[11] Pan, N., Sun, G. (2011). Functional Textiles for improved performance protection and health. In: Woodhead publishing Series in Textiles in association with The Textile Institute, Cambridge England.

[12] Rosace, G., Migani, V., Guido, E., Colleoni, C. (2015). Flame retardant finishing for textiles, In Flame Retardants, 209-246, Springer, Cham.

[13] Kotresh, T.M., Indushekar, R., Subbulakshmi, M.S., Vijayalakshmi, S.N., Prasad, A.K., Agrawal, A.K. (2006). Evaluation of Commercial Flame Retardant Polyester Curtain Fabrics in the Cone Calorimeter,Journal of Industrial Textiles, 36(1), 47-58, doi: https://doi.org/10.1177/1528083706064379.

[14] Carosio, F., Laufer, G., Alongi, J., Camino, G., Grunlan, J. C. (2011). Layer-by-layer assembly of silica-based flame retardant thin film on PET fabric. Polymer Degradation and Stability, 96 (5), 745-750.
[15] Yang, C. Q., He, Q., Lyon, R. E., Hu, Y. (2010). Investigation of the flammability of different textile fabrics using micro-scale combustion calorimetry. Polymer Degradation and Stability, 95(2), 108-115. doi: https://doi.org/10.1016/j.polymdegradstab. 2009.11.047.

[16] Beesoon, S., Behary, N., Perwuelz, A. (2020). Universal masking during COVID-19 pandemic: Can textile engineering help public health? Narrative review of the evidence, Preventive medicine, 139 (2020), 106236.

[17] Pavlidou, V. (2005). New multifunctional textiles: antimicrobial treatments. In "Proceedings of the Intelligent Textile Structures-Application, Production and Testing International Workshop", Thessaloniki, Greece, 2005.

[18] Purwar, R., Joshi, M. (2004). Recent Developments in Antimicrobial Finishing of Textiles. A Review. AATCC review, 4(3), 22-26.

[19] Williams, J.F. (2005). Antimicrobial functions for synthetic fibers: recent developments, AATCC review, 5, 17-21.

[20] Đorđević, D., Čalija, R., Stanković, M. (2014). The new textile materials and products with antimicrobial properties, Tekstilna industrija, 62(1), 32-38.

[21]TREVIRA CSThe Brand For Flame-Retardant Textiles (https://www.trevira.de/en/trevira-cs-flameretardant-textiles, available: 16.12.2020).

[22] Hu, J. (2008). Introduction to fabric testing. In Fabric Testing (1-26), Woodhead Publishing.

[23] ISO 13937-2-:2002. Textiles-Tear properties of fabrics-Part 2: Determination of tear force of trouser-shaped test specimens (Single tear method).

[24] ISO 9237 (1995). Determination of the permeability of fabrics to air, Geneva, Switzerland.

[25] Hu, J., Chan, Y. F. (1998). Effect of fabric mechanical properties on drape. Textile Research https://doi.org/10.1177\%2F004051759806800107

[26] Can, Y., Kirtay, E. D. (2007). Yarn characteristic's effects on tear resistance of cotton plain fabrics. Afyon Kocatepe University, Journal of Science and Engineering, 7(2), 65-78.

Primljeno/Received on: 17.01.2021.

Revidirano/ Revised on: 14.02.2021.

Prihvaćeno/Accepted on: 16.02.2021.

(C) 2021 Authors. Published by Union of Textile Engineers and Technicians of Serbia. This article is an open access article distributed under the terms and conditions of the Creative Commons Attribution 4.0 International license (CC BY) (https://creativecommons.org/licenses/by/4.0/) 